\title{
Influence of Social Capital on Livelihood Outcomes for the Internally Displaced Persons in Kenya: A Social Capital Approach
}

\author{
Christopher Nkonge Kiboro \\ Chuka University,Faculty of Arts and Humanities, \\ Department of Arts and Humanities, Chuka - Kenya
}

doi: 10.19044/esj.2017.v13n26p266 URL:http://dx.doi.org/10.19044/esj.2017.v13n26p266

\begin{abstract}
Social capital is increasingly recognized as important in influencing economic development, establishment of safe neighborhoods and wellfunctioning communities. There is growing evidence that communities with relatively higher stocks of social capital in form of grassroots associations appear to achieve higher levels of growth compared to societies with low stocks of social capital. This study sought to investigate the influence of social Capital on the livelihood outcomes for the internally displaced persons in Kenya. Membership to local level associations was used as a predictor of social capital. The study revealed that majority of the households that were affiliated to local level associations obtained essential services that influenced their livelihoods positively. Overall, the findings reveal that memberships in local associations (social capital) tend to insulate households from risks and other exigencies. The study recommends that government and other stakeholders such as non-governmental organizations should formulate projects and programs that seek to promote wider participation in local level associations particularly by the poor and those whose livelihoods are vulnerable.
\end{abstract}

Keywords: Social capital, Internally displaced persons, Livelihood, Local level associations

\section{Introduction}

Social capital, often characterized by a variety of elements such as norms, trust and density of social networks and the nature of interpersonal relationships common to the members of a specific group, is increasingly recognized as a dominant paradigm in the quest for social and economic development. Other important dimensions of social capital include rules and norms governing social action, network resources, informal social ties and 
formal ties, political liberties and civic community, groups and networks, trust and solidarity, collective action and cooperation, information and communication, and social cohesion and inclusion among other aspects (Putnam, 1993; Grootaert et al., 2004).

Social capital to the extent that it is the property of social environment, produces valuable resources that can be used to solve a broad range of problems in the society. Its function appears to be related to facilitating achievement of some societal good such as economic growth, social and political developments (Coleman, 1988; Putnam, 1993). Consequently, social capital is gaining global recognition particularly among international organizations particularly the World Bank (World Bank, 1998). The associations which come as complements of informal institutions allow their members to express their needs and to generate financial and human capabilities necessary to supplement their welfare improvement efforts. Evidence exists around the world that these associations improve economic efficiency by reducing costs, facilitating access to markets, agricultural inputs and access to credit (Narayan and Pritchett, 1997; Grootaert and van Bastelaer, 2002; Isham, 2002). However, despite the growing literature on associative life (social capital), empirical evidence on the influence of social capital on the livelihood outcomes for the internally displaced persons (IDPs) in Kenya is largely scarce.

Internal displacement of persons spells out today's biggest humanitarian problem confronting both the national governments and international organizations such as UNHCR (Ferris, 2011). The problem of internal displacement has persisted in Kenya many years after achieving independence (Refugee Consortium of Kenya 2005). In the recent past, the phenomenon of displacement has increased at an unprecedented rate. For example, in 1992, 1997 and 2000, mass displacement of people occurred in the country (Kenya Human Rights Commission (KHRC), 1998). In 1992, 300,000 people were displaced in the Rift Valley, parts of Nyanza and Western provinces (Katumanga, 2001). More recently, in 2007/2008 more than 600,000 persons were internally displaced from their farms and/or workstations (Internal Displacement Monitoring Center, 2010). Although the government commenced resettlement programs, there are IDPs who are presently living in camps and others integrated in the host communities.

The presence of the internally displaced persons in some parts of Kenya up till now is a clear indication that so far no durable solution has been found. As a result, there is increased suffering and impoverishment of the populations that were once economically stable. Despite the government efforts to resettle displaced persons, the humanitarian situation of IDPs is unsatisfactory because most of them are yet to re-establish their livelihoods. Most returnees have no adequate shelter, food and clothing and since most of 
them are peasants, they have no capital for obtaining farm inputs and equipment for recovering their livelihoods.

To cope with this reality, IDPs organize themselves into social structures in the form of self-help groups and social networks to enable members obtain essential commodities for their everyday life. Office for the Coordination of Humanitarian Affairs-Kenya (OCHA) (2009) indicates that in 2009 there were eighteen self-help groups consisting of a total of 6,711 households of victims of internal displacement. The emergence of such social groups can be attributed to features of local level organization which include trust, shared norms and social networks which fall under the broader concept of social capital. Therefore, as IDPs continue to organize themselves into associative life, the remaining question is whether these associations have any influence on their livelihood outcomes. Thus this paper analyzes the contribution of social capital in improving livelihoods for vulnerable populations with a special focus on IDPs.

\section{Literature Review}

\section{Social Capital and Welfare Outcomes}

It is well established that social capital helps households escape from poverty (Grootaert et al., 2002). Woolcock (2001) argues that societies with high stocks of social capital are less vulnerable, and have greater capacity to resolve their own conflicts as well as take advantage of new opportunities for improvement. Hence the central idea of social capital is that networks and the associated norms have value (Putnam, 2000). Studies on social capital in Bolivia, Burkina Faso, and Indonesia by Grootaert and Narayan (2000), Grootaert et al., (2002), and Grootaert (2000) revealed that certain aspects of social capital contributed significantly to the household welfare.

Evidence is provided in the literature that social capital has positive effects on household welfare (Grootaert, 1999; Grootaert et al., 2002; Narayan and Pritchett, 1997; and Woolcock and Narayan, 2000). These studies show that households (particularly the poor ones) draw additional resources that enables them meet every day needs through social connections; thus the reciprocal relationships serve as wells of financial, social, or political support from which they can draw during times of need. Furthermore, Grootaert et al., (2002) found that households with active ties in local associations (rich in social capital) have better access to credit, even if financial matters were not the primary objective of such associations.

Rosenzweig, (1988); Fafchamps, (1992); Townsend, (1994); Udry, (1994); Gakuru, (2002); Fafchamps and Lund, (2003); and Bastelaer, (2003) argue that where there are no formal financial institutions and insurance opportunities, especially in developing countries, many people rely on informal community structures to provide not only financial security, but 
also social security and reduce exposure to risks. Narayan and Pritchett (1997) points out that social capital may serve as an informal insurance thus mitigating the consequences of adverse outcomes. This suggests that communities with higher stocks of social capital may pursue higher returns but riskier activities because there is greater sharing of household risk. This in turn would result to higher income. A key role in this respect is played by kinship networks whose membership is ascribed using the criteria of bloodlines, clans, marriage, or adoption.

Research has also shown that social capital encourages co-operative behavior, thereby facilitating economic welfare through improved information sharing and reduction of opportunistic behavior (because of norms that sanction behavior) (Cummings et al., 2006; Grootaert et al., 2004; Grootaert, 1997; Putnam, 1993; Uphoff and Wijayaratna, 2000; and Woolcock and Narayan, 2000). Similarly, Narayan and Pritchett (1997) contends that communities with higher stocks of social capital are more likely to lower transaction costs, and reduce uncertainty because such communities have more and better information, therefore they don't suffer from information asymmetry. Bigsten et al., (2000) also explains that entrepreneurs rely on their networks to reduce information asymmetries by facilitating flows of information about previous conduct, the present situation and the anticipated behavior of their trading partners, debtors and creditors. Portes and Sensenbrenner (1998) in a study of economic communities among Asian, Middle East and other immigrant communities found out that entrepreneurship was encouraged by social capital based on solidarity.

Burt (1992) found out that networks can affect enterprise performance directly by providing entrepreneurs with information about the world, especially with regard to technologies and markets. Thus, according to Burt (1992) social capital increases the capacity to share knowledge. Nahapiet and Ghoshal (1998) also recognize social capital as an important aid to adaptive efficiency, creativity, and learning. Hence the concept of social capital is central in understanding institutional dynamics, innovation and value creation.

Social capital also plays a significant role in enterprise performance. This is evidenced by Putnam (1993) work in Italy where it was reported that for institutional reasons, some regions had prospered while others were static. The explanation provided by the study for the difference between the southern and northern regions of Italy, was that communities in northern parts of Italy were more successful because of strong norms for reciprocity and dense networks of civil engagement that made co-operation more likely as opposed to communities in south of Italy (Kimuyu, 2000). Bazan and Schmitz (1997) concur with Putnam's (1993) conclusion about the differences in prosperity between north Italy and south Italy by arguing that 
the quality of interaction among people has a strong influence on business enterprises and economic performance. Fukuyama (1999) makes a similar point; that abundant stock of social capital produces a dense of civil society which facilities the functioning of modern democracy.

Narayan and Pritchett (1997) extends the argument that abundant stock of social capital facilitates the functioning of modern democracy by pointing out that there are various ways in which social capital could lead to improved social welfare. First, higher social capital improves efficiency in the provision of public services and the performance of government. They indicate that this is possible through high levels of voluntary participation and enhanced monitoring of public services. Secondly, higher social capital may facilitate development of cooperative behavior within the community which can help in avoiding the "tragedy of commons" through collective safeguarding of public utilities. This would result in better use of common property and benefit most of the members of the community.

Narayan and Pritchett (1997) point out that membership to highly interconnected systems have a positive correlation with the early adoption of innovations. Thus, new technology may diffuse at a faster rate in communities with higher social capital, consequently achieving higher economic growth and development. For example, Isham (1999; 2002) provides evidence from rural households in Tanzania on how the characteristics of social structures affect the adoption of fertilizer and improved seeds. The concept of social capital has also been widely used in the context of disadvantaged and marginalized territories especially at a village or neighborhood level to explain trends of neighborhood improvement and social unity with the wider society (Forrest and Kearns, 2001; Green et al., 2005). Lang and Hornburg (1998) had previously made an assertion that initiatives of neighborhood improvement are more effective in areas rich in social capital. Woolcock and Narayan (2000) have argued that having social ties and relation with others in society can have positive socioeconomic outcomes not only for the individual, but also to the wider community. Moreover, they have argued that communities endowed with higher stock of social capital are perceived to be in a better position to deal with poverty and vulnerability and the converse.

Studies at the micro-level have examined the relationship between social capital and household income. For instance, Narayan and Pritchett (1997), in their study among households in rural Tanzania, found that social capital is one of the most important determinants of households' income. They further found that households in villages with more social capital are more likely to enjoy better public services, use advanced agricultural practices and use credit for agricultural improvement. Other studies have examined the role of social capital in relation to employment and career 
success. For example, it has been found that social capital does not only help workers find jobs (Granovetter, 1973; 1995; Lin and Dumin, 1996; Lin, Ensel and Vaughn, 1981) but it also influences career success (Burt, 1992; Padolny and Baron, 1997; Gabbay and Zuckerman, 1998).

\section{Methods}

The study was done in Nakuru County and Uasin Gishu County. Since 1992 ethnic clashes in the Rift Valley, Nakuru County and Uasin Gishu County have persistently and enormously been affected by clashes of ethnic nature with a large number of people being displaced. The 2007 political violence was the worst of all making the two Counties the host of the largest number of IDPs in the country. It is on this basis that the two counties were purposively selected and considered representative of other counties in the country. Due to the geographical vastness of the two counties, a multi-stage cluster sampling was widely used because it would have been too difficult, costly, and lengthy to cover the entire area with random sampling. Three levels of clusters were defined. In the first level, constituencies in each of the counties were the primary clusters. The Constituency Assembly Ward was defined as the second level cluster and then village units were defined as the third level cluster. In every county, five constituencies (primary clusters) were randomly sampled. From each of the selected primary (first level) clusters, two (2) constituency assembly wards (second level clusters) were randomly selected. This resulted to ten (10) second level clusters from each county. From the ten second level clusters, a total of 20 village units, two per constituency assembly ward were randomly selected. The same was done in the other county. After the village units (third level clusters) were randomly selected, households list for every village unit was developed with the assistance of the assistant chief. Ten households were then selected from each cluster using systematic sampling method. Since there were 20 clusters in every county, a total of 200 respondents were sampled from each county. Questionnaires were used as the primary tools for data collection.

\section{Data Analysis and Discussion Membership in Social Groups}

A close observation of group membership status in the study area reveals that a large number of households belonged to social groups. The data in Table 1 show that 73.8 per cent of the total households that were sampled were members of social groups. Using membership as a predictor of social capital, it is evident from the data that there are high levels of social capital among the sampled households. Social capital is said to have the potential of reducing the probability of being poor and the returns to 
household investment in social capital are higher for the poor (Grootaert et al., 2002). Based on Grootaert et al., (2002) assertion, the observed large membership to social groups by households can be attributed to the anticipated returns from investment in such groups that are perceived to have a direct and positive impact on the households' livelihood. After displacement, households and individuals suddenly find themselves stripped of their means of survival.

Displacement leads to massive loss not only of income, land, or other forms of property, but also of less tangible symbolic goods such as cultural heritage, friendships and a sense of belonging to a particular place. Its effects on individuals and families are wide ranging and include impoverishment, social isolation, and exclusion from mainstream social services such as health, welfare and education provision. Therefore, it is households in such circumstances would largely be compelled by poverty to adopt strategies beyond individual efforts and incorporate systematic mobilization and coordination of activities at the village and community levels.

Table 1: Group Membership

\begin{tabular}{ccc}
\hline Variables & Frequency & Percentage \\
\hline Group membership & & \\
Yes & 295 & 73.8 \\
No & 105 & 26.2 \\
Total & 400 & 100.0 \\
\hline
\end{tabular}

\section{Purpose of Belonging to a Community Group}

Different people join groups for different reasons and motivations. However, the key assumption is that the social groups and networks built through interactions have measurable benefits to the participating individuals, and result, directly or indirectly, to a higher level of well-being. This proposition was tested empirically by asking the respondents to state the main purpose for joining the group(s).

When asked what the most important reason for joining group was, 37.0 per cent of the total respondents indicated that the main purpose for belonging to a group was to improve their household's current livelihood including access to services. Indeed this is a compelling reason to join social groups since most of the people who were internally displaced during the 2007/2008 post-election violence incurred huge losses including loss of livelihood. A significant proportion had their vital documents destroyed or lost in the process thus accessing basic services for them is extremely difficult. Hence, belonging to a group provides latitude for accessing basic services.

A sizeable number of households $(22.8 \%)$ also indicated that their main purpose for belonging to a group was to benefit the community. This may be explained by the fact that most of the returnees had a lot of needs 
hence the feeling that membership into groups could have a utilitarian function to the returnees. There are times when more than one person is needed to accomplish or address a felt need. This means that there is need for people to come together in form of a group to pool talents, knowledge, or resources in order to get the work done. In such circumstances individuals may find the need to join groups to work with others.

Spiritual, social status and self-esteem benefits were indicated by 8.5 per cent of the households as the purpose for belonging to social groups. According to Spitzer and Twikirize (2014), during conflicts populations suffer from long-lasting psycho-social effects associated with traumatic experiences, witnessing of violent acts, loss of livelihoods, and personal humiliation and abuse. It is therefore plausible that individuals with such experiences will be compelled by their circumstances to belong to groups because they (groups) provide therapeutic benefits. This finding is with Nzuve's (1999) argument that 'groups can increase people's feelings of selfworth. In addition to conveying status to those outside the group, membership can raise the feelings of self-esteem which is also bolstered when people gain acceptance in highly valued group, p.30”.

Insurance in times of emergency was also identified as the purpose for belonging to a group by 5.3 per cent of the sampled households. Only one (1) household indicated enjoyment and recreation as the main purpose for belonging to a group. This was too small to make any significant comparison.

It is evident from the responses that apart from the material benefits obtained by virtue of being a member of the group, many victims of internal displacement value the possibility of resorting to social groups for help whenever a need arises. It is also apparent that social groups played a significant role in improving the economic conditions of the internally displaced persons' households.

Table 2: Reasons for Joining Groups

\begin{tabular}{ccc}
\hline Variables & Frequency & Percentage \\
\hline To improve my household's current livelihood or & 148 & 37.0 \\
access to services & & \\
As insurance in times of emergency & 21 & 5.3 \\
To benefit the community & 91 & 22.8 \\
For enjoyment $\backslash$ Recreation & 1 & 0.3 \\
For spiritual, social status and self-esteem & 34 & 8.5 \\
Total & 295 & 73.8 \\
\hline
\end{tabular}

The above findings reveal that by belonging to a community association one may derive many benefits (social capital) that can impact positively on the overall household well-being. For example, one can benefit from material goods and services such as food, clothes, housing, health care, 
schooling etc. Moreover, the findings reveal that in stressful situations, social networks may have a therapeutic effect by reducing the perceived importance of the problem or providing an avenue for ventilating emotions. Affiliation to social support network may increase a member's sense of selfefficacy and control.

\section{Influence of Social Capital on Households' Livelihoods}

The nature and extent of our social relationships (social capital) have an important impact on our lives but they are especially significant for poor people with little material assets, modest income or formal education (Woolcock, 2002). It is on this basis that in this section the basic question on whether membership to local level associations has improved the livelihoods of IDPs is addressed. It critically examines the benefits of group membership and whether such benefits brought about improvement in households' livelihood. The impact of social capital on households' livelihood was captured by assessing the extent to which households were able to access the various welfare enhancing services and inputs from both the groups and networks that households were members. First, the respondents were asked whether after displacement they received support from their associations and networks.

The extent to which households were helped by their groups and associations to access the various services that were basic in improving their households' livelihoods is summarized in Table 3. A substantial majority 93.5 per cent acknowledged to have received support from their groups. The majority of the respondents 92.5 per cent reported to have been helped by their groups and associations in accessing education services. Education is a strong and robust predictor of well-being. Education broadens individual's social knowledge with the cognitive and perceptual experiences acquired within and outside academic programs; widens the frontiers of individuals in terms of economic and social possibilities; and makes individuals more open-minded to accept otherness from heterogeneous groups. Education is also essential for household members to accumulate human capital through schooling and training thus increasing their productive capacity which ultimately translates to improved household well-being. 
Table 3. Local Level Associations and Access to Essential Livelihood Services

\begin{tabular}{|c|c|c|c|c|}
\hline Question & \multicolumn{3}{|c|}{ Response } \\
\hline & \multicolumn{2}{|c|}{ Yes } & Norcentage \\
\hline $\begin{array}{c}\text { Did you receive any } \\
\text { support from your } \\
\text { association? }\end{array}$ & Frequency & Percentage & Frequency & Perc \\
\hline $\begin{array}{c}\text { Has your group, } \\
\text { association or network or } \\
\text { helped you or your } \\
\text { household get access to: }\end{array}$ & 374 & 93.5 & 26 & \\
\hline Education & 370 & 92.5 & 30 & \\
\hline Health services & 365 & 91.2 & 35 & 8.5 \\
\hline $\begin{array}{c}\text { Water supply and } \\
\text { sanitation }\end{array}$ & 344 & 86.0 & 56 & 14.0 \\
\hline Credit or savings & 384 & 96.0 & 16 & 4.0 \\
\hline $\begin{array}{c}\text { Agricultural input or } \\
\text { technology }\end{array}$ & 363 & 90.7 & 37 & 9.3 \\
\hline Construction material & 359 & 89.7 & 41 & 10.3 \\
\hline Information & 380 & 95.0 & 20 & 5.0 \\
\hline Employment & 252 & 88.0 & 48 & 12.0 \\
\hline Food supply & 361 & 90.2 & $39)$ & 9.8 \\
\hline Security & 253 & 63.3 & 147 & 36.7 \\
\hline
\end{tabular}

With regard to health services, 91.2 per cent of the respondents indicated they received help from their groups. Most of the displaced households often suffer from poor health due to increased exposure to disease causing elements as a result of either congestion or/and poor sanitation. Thus access to health services is an important indicator of household welfare. Households that experience illness and cannot afford health care services; their general welfare is highly likely to diminish since illness undermines the optimal productivity of such households. This is because other than the sick member incapacitated by disease some family members may have to forgo participating in economically productive activities and remain at home to nurse the sick member(s). This deprives of the household income that is essential for smoothing household consumption.

Out of all the households interviewed, 86.0 per cent reported that they received support in accessing water and sanitation services. Just like health services, water and sanitation is an essential welfare parameter. Various uses of water provide a broad range of benefits: food production (crops, livestock, fish), income (from the sale of products dependent on water), reduced drudgery as a result of water fetching, and improved health. Lack of access to water and sanitation services can cause disease morbidity within households which can even increase mortality rates. These benefits 
usually reinforce each other. Consequently, the level of poverty within households is reduced.

A major characteristic of displaced populations is the recurrent exposure to income shocks. Access to credit and savings services is an effective way of insulating households from the risk of income instability. The study sought to determine the extent to which the displaced households received support from groups and social networks in accessing credit. An overwhelming majority of 96.0 per cent of the total respondents acknowledged to have been supported with credit. Ideally, poor households are usually not able to provide collateral to obtain credit from formal lending institutions. Hence, there is over-reliance on local money lenders and group credit. Access to credit services is a key welfare factor as it enables poor household obtain capital for investment and improving other household capitals including human capital.

Majority of the households sampled engaged in farming as their primary occupation. This suggests that access to agricultural inputs and technology is a key determinant of their households' welfare. The survey revealed that a substantially high number of respondents 90.7 per cent benefitted from social networks in accessing agricultural and technology services. Access to these services can significantly improve the welfare of households. Overall, social networks and associations were critically instrumental in helping internally displaced persons access vital welfare enhancing services including house construction materials (89.7.0\%), information (95.0\%), employment (88.0\%), food supply (90.2\%), and security $(63.3 \%)$. These benefits combined, lead directly to a higher level of household's well-being.

\section{Conclusion}

In light of the above results, it is demonstrable that social capital indeed plays a vital role for people and communities experiencing economic disadvantages. The willingness to provide help to a neighbor is a manifestation of existence of effective community institutions in form of norms of trust and reciprocity (social capital). Abundance of norms of trust and reciprocity help people to come together to collectively address problems they face in common and achieve outcomes of mutual benefit. Hence social groups and associations (social capital) at the grassroots are instrumental in enabling poor families and individuals to "get by" or "get ahead". To insulate households from risks and other shocks, the government and other stakeholders such as non-governmental organizations should formulate projects and programs that seek to promote wider participation in local associations particularly by the poor and those whose livelihoods are at risk. 


\section{References:}

1. Bazan, L. and Schmitz, H. (1997). Social Capital and Export Growth: An Industrial Community in Southern Brazil. IDS Working Paper No. 361, Sussex.

2. Bastelaer, T. (2003). Does social capital facilitate the poor's access to credit-A review of microeconomic literature. Social Capital Initiative Working Paper, No, 8-03. The World Bank, Washington, D.C, USA.

3. Bigsten, A., P. Collier, S. Dercon, M. Fafchamps, B. Gauthier, J. W. Gunning, A.Oduro, R. Oostendorp, C. Pattillo, M. Soderbom, F. Teal and A. Zeufack (2000). "Contract Flexibility and Dispute Resolution in African Manufacturing”, Journal of Development Studies, 36 (4): $1-37$.

4. Burt, R. (1992). Structural Holes. The Social Structure of Competition. Cambridge MA: Harvard University Press.

5. Coleman, J. S. (1988). "Social Capital in the Creation of Human Capital", American Journal of Sociology, Vol, 94 (supplement): S95S120.

6. Cummings, S., Heeks, R.; and Huysman, M. (2006). "Knowledge and learning in online networks in development: a social-capital perspective", Development in Practice, Vol 16, No.6, 570-586.

7. Fafchamps, M. (1992). "Solidarity Networks in Pre-industrial Societies: Rational Peasants in a Moral economy", Economic Development and Cultural Change, 41(2): 147-173.

8. Fafchamps, M. and S. Lund (2003), "Risk-Sharing Networks in Rural Philippines." Review of Economic Studies, Vol. 71, 261-287.

9. Ferris, E. (2011). Climate Change and Internal Displacement: A Contribution to the Discussion. A Paper Presented at UNHCR Bellagio Roundtable, on 22-26 February 2011.

10. Forrest, R. and Kearns, A. (2001). "Social Cohesion and Neighborhood Regeneration", Urban Studies, 38, 2125-2143.

11. Fukuyama, F. (1999). Social Capital and Civil Society. Paper presented at the International Monetary Fund Conference on Second Generation Reforms. The Institute of Public Policy. George Mason University. United States of America.

12. Gabbay, S. M. and Zuckerman, E. W. (1998). "Social capital and opportunity in corporate R\&D: The contingent effect of contact density on mobility expectations", Social Science Research, 27: 189217.

13. Gakuru, O. N. (2002). "Globalisation of Social Structure and Politico-economic Development in Kenya", African Journal of Sociology, Vol.5, No. 1: 23-38. 
14. Granovetter, M. (1973). "The strength of weak ties", American Journal of Sociology, 78(6): 1360-1380.

15. Granovetter, M. S. (1995). Getting a job: A study of contacts and careers ( $2^{\text {nd }}$ Ed.). Chicago: University of Chicago Press.

16. Green, G., M. Grimsly and B. Stafford. B. (2005). The Dynamics of Neighborhood Sustainability. York: York Publishing Services.

17. Grootaert, C, (1997) 'Social Capital: The Missing Link?', in Expanding the Measure of Wealth - Indicators of Environmentally Sustainable Development, Washington DC: World Bank.

18. Grootaert, C. (2000), Social Capital, Household Welfare and Poverty in Indonesia, Mimeo, World Bank.

19. Grootaert, C. and D. Narayan (2000), "Local Institution, Poverty and Household Welfare in Bolivia", Local Institutions Working Paper No. 9, Washington D.C., World Bank, Social Development.

20. Grootaert, C. and van Bastelaer, T. (2002). Understanding and Measuring Social Capital: A Synthesis of Findings and Recommendations from the Social Capital Initiative. Washington DC: World Bank.

21. Grootaert, C.; Narayan, D.; Jones, V. N. and Woolcock, M. (2004) Measuring Social Capital. An Integrated Questionnaire. Washington D.C: World Bank.

22. Grootaert, C.; Oh, G. T.; and Swammy, A. (2002). "Social Capital, Household Welfare and Poverty in Burkina Faso", Journal of African Economies, Vol 11, No.1, 4-38.

23. Internal Displacement Monitoring Centre (IDMC) (2010). Kenya: Speedy reform needed to Deal with past Injustices and Prevent Future Displacement. IDMC.

24. Isham, J. (1999) "The Effect of Social Capital on Technology Adoption: Evidence from Rural Tanzania”, Paper presented at the Annual Meeting of the American Economic Association, New York City.

25. Isham, J. (2002). "The Effect of Social Capital on Fertilizer Adoption: Evidence from Rural Tanzania", Journal of African Economies, Vol.11, No. 1, 39-60.

26. Katumanga, M. (2001). 'The Moral Imperatives of Conflict in Kenya', In Kenya at Crossroads: Scenarios for the Future. Nairobi: Institute of Economic Affairs (IEA)/SID.

27. Kenya Human Rights Commission (1998). Killing the Vote: State Sponsored Violence and Flawed Elections in Kenya, Kenya Human Rights Commission Report. Nairobi: KHRC. 
28. Kimuyu, P. (2000). Institutions Relevant to Commerce and Industry. Moral norms, Social capital, The State and the Law. IPAR Discussion Paper Series, No. 021. IPAR.

29. Lang, R. E. and Hornburg, P. (1998). "What Is Social Capital and Why is it Important to Public Policy?" Housing Policy Debate, 9, 115.

30. Lin, N. and Dumin, M. (1986) 'Access to occupations through social ties.' Social Networks, 8:365-85.

31. Lin, N., Ensel, W. M. and Vaughn, J. C. (1981). "Social resources and strength of ties: Structural factors in occupational status attainment", American Sociological Review, 46: 393-405.

32. Nahapiet, J. and S. Ghoshal (1998). "Social Capital, intellectual capital and the organizational advantage", Academy of Management Review 23 (2): 242-66.

33. Narayan, D. and Pritchett, L. (1997), "Cents and SociabilityHousehold Income and Social Capital in Rural Tanzania", Policy Research Working Paper No. 1796. Washington D.C: World Bank.

34. Nzuve, S. N. M (1999). Elements of Organizational Behaviour. Nairobi: University of Nairobi Press.

35. Office for the Coordination of Humanitarian Affairs-Kenya (2009), Kenya IDP Fact Sheet. Nairobi: OCHA.

36. Padolny, J. M. and Baron, J. N. (1997). "Resources and relationships: Social networks and mobility in the workplace", American Sociological Review, 62: 673-693.

37. Portes, A. and Sensenbrenner, J. (1998). Embeddedness and immigration - notes on the social determinants of economic-action. American Journal of Sociology, 98, 1320- 1350.

38. Putnam, R. D. (1993). Making Democracy Work: Civic Traditions in Modern Italy. Princeton, NJ: Princeton University Press.

39. Putnam, R. D. (2000) Bowling Alone: The Collapse and Revival of American Community. New York: Simon and Schuster.

40. Refugee Consortium of Kenya (2005). The Problem of Internal Displacement in Kenya. Refugee Consortium of Kenya.

41. Rosenzweig, M. R. (1988). "Risk, implicit contracts and the family in rural areas of low-income countries", Economic Journal, 98(393): 1148-1170.

42. Spitzer, H. and Twikirize, J. M. (2014) "Armed Conflict and Political Violence in Africa's Great Lakes Region: Challenges for Social Work Education and Practice", In Spitzer, H., Twikirize, J. M and Wairire, G. G. (Eds.), Professional Social Work in East Africa: Towards Social Development, Poverty Reduction and Gender Equality, Kampala: Fountain Publishers. 
43. Townsend, R. (1994). "Risk and insurance in village India", Econometrica. 62(3): 539-591.

44. Udry, C. (1994). "'Risk and insurance in a rural credit market: an empirical investigation in Nothern Nigeria", Review of Economic Studies, 61(3): 495-526.

45. Uphoff, N. and Wijayaratna, C. M. (2000) "Demonstrated benefits from social capital: the productivity of farmer organizations in Gal Oya, Sri Lanka”, World Development 28 (11):1875-90.

46. Woolcock, M. (2002). Social Capital in Theory and Practice: Where do we stand? In Isham, J., Kelly, T. and Ramaswamy, S. (Eds.), Social Capital and Development Economic: Well-Being in Developing Countries. Northampton, MA, USA: Edward Elgar Press. Pp. 18-39.

47. Woolcock, M. and Narayan, D. (2000) "Social capital: implications for development theory, research, and policy", World Bank Research Observer 15(2): 225-49.

48. World Bank (1998) 'The Local Level Institutions Study: Program Description and Prototype Questionnaires', Local Level Institutions Study Working Paper No.2, Social Development Department, Washington DC: World Bank. 